\title{
Retrospective Evaluation of Pediatric Patients with Extremity Pains
}

\section{Ekstremite Ağrısı ile Çocuk Polikliniğine Başvuran Çocuk Hastaların Retrospektif Değerlendirilmesi}

\section{(D) Sezin Naiboğlu¹, (D) Emrah Naiboğlu², (D) Özden Aksu Sayman³, (D) Fatma Gül Demirkan4}

${ }^{1}$ Esenyurt Necmi Kadıoğlu State Hospital, Clinic of Child Health and Diseases, İstanbul, Turkey

2SBÜ İstanbul Bakırköy Training and Research Hospital, Clinic of Child Health and Diseases, İstanbul, Turkey

${ }^{3}$ Ordu University Training and Research Hospital, Clinic of Child Health and Diseases, Ordu, Turkey

4SB Kanuni Training and Research Hospital, Clinic of Child Rheumatology Child Health and Diseases, İstanbul, Turkey

Abstract

Objective: Recurrent lower extremity pains (growing pains) are the most common non-inflammatory cause of musculoskeletal pain in children. This study aims to investigate musculoskeletal symptoms that may be associated with vitamin D deficiency. We retrospectively examined the data of the patients who applied to the pediatric outpatient clinic and who had vitamin $D$ levels measurement results.

Method: We retrospectively evaluated the clinical, laboratory, and diagnostic findings of patients aged 3-16 years, who presented to our outpatient clinic with growing pains between January 2019 and December 2019. We excluded patients with chronic diseases, those with joint findings that might be associated with rheumatological or orthopedic diseases, and those who used vitamin D supplements.

Results: There were a total of 103 subjects. Forty-eight subjects were female (46.6\%) and $55(53.4 \%)$ were male. The mean age of the subjects was $8.8 \pm 4.2$ years (3-16). The mean serum 25 -hydroxyvitamin $D$ $[25(\mathrm{OH}) \mathrm{D}$ ] level of the subjects was $15.4 \pm 6.5 \mathrm{nmol} / \mathrm{L}$. The subjects were categorized according to their $25(\mathrm{OH}) \mathrm{D}$ levels. Ten subjects $(9.7 \%)$ had severe vitamin D deficiency, 25 (23.4\%) had vitamin D deficiency, and 42 (40.8\%) had vitamin D insufficiency.

Conclusion: Leg pains are common in children, and growing pains are the most common non-inflammatory causes of muscle-joint pain in children. Patients with musculoskeletal pain should be screened for vitamin D deficiency. In this study, we aimed to emphasize the importance of vitamin $D$ level assessment in patients presenting with joint-muscle pains that were primarily evaluated as growing pains.

\section{Öz}

\begin{abstract}
Amaç: Tekrarlayan alt ekstremite ağıları (büyüme ağrıları) çocuklardaki kas-iskelet sistemi ağrılarının enflamatuvar olmayan en sık sebebidir. Bu araştırmada çocuk polikliniğine kas iskelet sistemi şikayetleriyle başvuran ve $D$ vitamini düzeyi bakılan hastaların verilerini inceledik. Böylece $D$ vitamini eksikliği ile ilişkili olabilecek kas iskelet sistemi semptomlarını araştırmayı amaçladık.
\end{abstract}

Yöntem: Polikliniğimize Ocak 2019-Aralık 2019 tarihleri arasında eksremite ağrısı ile başvuran 3-16 yaş grubundaki çocukların klinik özellikleri, tetkik sonuçları ve tanılarına ait bilgiler retrospektif olarak incelendi. Kronik hastalığı olan, romatolojik veya ortopedik olabilecek eklem bulgusu olan ve $D$ vitamini kullanan hastalar çalışma dışı bırakıldı.

Bulgular: Çalışmamıza katılan 103 çocuğun 48'i $(\% 46,6)$ kız, 55'i $(\% 53,4)$ erkekti. Çocukların yaşları 3-16 yaş aralığında olup, ortalama yaşı 8,8 $\pm 4,2$ idi. Çocukların ortalama serum $25(\mathrm{OH})$ D vitamin düzeyi $15,4 \pm 6,5$ olarak saptandı. Serum $25(\mathrm{OH})$ D vitamin düzeyine göre gruplandırılan çocukların 10'unda $(\% 9,7)$ ağır D vitamini eksikliği, 25'inde $(\% 23,4)$ D vitamini eksikliği, 42'sinde (\% 40,8) D vitamini yetersizliği saptandı.

Sonuç: Çocuklarda bacak ağrısı şikayeti sık karşılaşılan bir durum olup, büyüme ağrıları gibi enflamatuvar olmayan nedenler kas-eklem ağrısının en sık sebebidir. Kas-iskelet ağrısı olan hastaların D vitamini eksikliği açısından mutlaka taranması gerekir. Çalışmamızda eklem-kas ağrısı şikayeti ile başvuran ve büyüme ağrısı düşünülen hastalarda vitamin $D$ düzeyi incelemesinin önemini vurgulamak istedik.

Anahtar kelimeler: Büyüme ağrısı, çocuk, D vitamini

Keywords: Child, growth pain, vitamin D

Address for Correspondence: Sezin Naiboğlu, Esenyurt Necmi Kadıŏlu State Hospital, Clinic of Child Health and Diseases, İstanbul, Turkey E-mail: sezin_ctnol@hotmail.com ORCID: orcid.org/0000-0002-9593-1136 Received: 24.03.2020 Accepted: 29.04.2020

Cite this article as: Naiboğlu S, Naiboğlu E, Sayman ÖA, Demirkıran FG. Retrospective Evaluation of Pediatric Patients with Extremity Pains. Bagcilar Med Bull 2020;5(2):40-44

(C) Copyright 2020 by the Health Sciences University Turkey, Bagcilar Training and Research Hospital Bagcilar Medical Bulletin published by Galenos Publishing House. 


\section{Introduction}

Recurrent lower extremity pains (growth pain) are the most common non-inflammatory cause of musculoskeletal pain in children (1).

The medical history of the child who experiences pain is significant for approaching the diagnosis. When obtaining the medical history, the location of the pain, the occurrence time of the pain, the duration and quality of the pain, the relationship of the pain with exercise, systemic findings accompanying the pain, vaccination status, nutritional habits, psychological state and trauma are the points that require attention (2). A full physical examination to be performed in the child who experiences musculoskeletal pain provides important data to the doctor.

Most frequently, growth pains are observed as the reason for applying to the doctor with a pain complaint in childhood. Growth pains are defined as the pains which may be experienced generally in the legs (in the back of the knee, thigh and calf) in children aged 3-12 years and these pains are less frequently in the arms, together with the legs, appear in the evening and at night, awaken the person, last from a few minutes up to a few hours, and are the cause of which is now known. The relationship between these pains and growth has not been demonstrated, and this reference is commonly used since it is the reason for consultation. In physical examination, no characteristic is detected even in the painful period. However, the symptoms of another disease should be sought carefully before establishing this diagnosis (3).

It has been put forward that the prevalence of low vitamin $\mathrm{D}$ in patients with non-specific musculoskeletal pain may be 38-93\% (4). Even though vitamin D deficiency primarily causes osteomalacia, the pain can cause nonspecific symptoms such as weakness (4). Besides, vitamin D deficiency is thought to be correlated with various pain syndromes. Vitamin deficiency can lead to severe skeletal pain, low back pain, non-inflammatory arthritis and joint stiffness even in healthy individuals (5).

The normal vitamin D level is defined as the serum vitamin D level, which prevents the development of rickets or osteomalacia, and keeps the parathormone (PTH) level within the normal range by enabling optimal absorption of calcium in the diet. The $25(\mathrm{OH})$ vitamin D level, above 32 $\mathrm{ng} / \mathrm{mL}$ in adults and $20 \mathrm{ng} / \mathrm{mL}$ in children, is considered as a normal level $(6,7)$.

Today, it has been realized that the effectiveness of vitamin $\mathrm{D}$ is not only limited to regulating calcium-phosphore homeostasis and bone metabolism, but also has proapoptotic, anti-inflammatory and immunomodulatory characteristics (8). For this reason, vitamin D deficiency, which is a preventable and treatable condition, is significant for patients experiencing musculoskeletal pain.

In this research, we examined the data of the patients who applied to the pediatric department with musculoskeletal complaints and whose vitamin D levels were examined. Hence, we wanted to research the musculoskeletal symptoms and to emphasize the importance of examining the vitamin D level in patients assumed to have growth pain.

\section{Materials and Methods}

The medical history, physical examination and laboratory tests of 103 children in the 3-16 years of age group, who applied to our pediatric outpatient clinic between January 2019 and December 2019 with extremity pain, were examined retrospectively for the differential diagnosis of the disease related to the musculoskeletal system. The demographic information, serum calcium, phosphore, alkaline phosphatase, PTH and $25(\mathrm{OH})$ vitamin D levels of the patients were evaluated. As a result of all the evaluations, the patients were diagnosed with growth pain according to the Peterson (3) criteria. Patients whose extremity pain depended on any organic disease and who had definite diagnosis, those with a chronic disease, those with possible rheumatological or orthopedic joint findings and patients who were taking vitamin D were excluded from the study.

According to Pediatric Endocrine Association, serum 25 $(\mathrm{OH})$ vitamin D levels above $20 \mathrm{ng} / \mathrm{mL}$ were classified as 'normal', $12-20 \mathrm{ng} / \mathrm{mL}$ as 'insufficient', $5-12 \mathrm{ng} / \mathrm{mL}$ as "deficiency" and $<5 \mathrm{ng} / \mathrm{mL}$ as "severe deficiency". Patients were divided into 3 groups as 3-6 years of age (play age), 7-11 years of age (school period), and 12-18 years of age (adolescence) according to their ages. The age groups and genders of the patients, their $25(\mathrm{OH})$ vitamin D levels and the classification of their levels were compared.

\section{Statistical Analysis}

Statistical analyses were conducted by means of IBM Statistical Package for Social Sciences 21.0 package program. The categorical data were expressed in frequency (n) and percentage (\%) for descriptive analysis, and the continuous data were expressed in mean \pm standard deviation and median (25. percentile-75. percentile). Normality distribution was decided with the coefficient of variation, histogram and normality tests. The chi-square 
test was used in the analysis of the categorical variables. The Mann-Whitney U test was employed to compare the continuous variables of two independent groups, because normality distribution could not be achieved. The Kruskal-Wallis test was implemented for the comparison of the continuous variables of more than two independent groups as normality conditions could not be fulfilled. The cases when the $\mathrm{p}$ value was below 0.05 were considered statistically significant.

\section{Results}

Of 103 children who participated in our study, 48 (46.6\%) were female and 55 (53.4\%) were male. The mean age of the children, whose ages varied between 3 and 16 years, was $8.8 \pm 4.2$ years. When classified by age, 36 (35\%) children were at play age (3-6 years of age), 38 (36.9\%) were at school age (7-11 years of age), and 29 (28.1\%) were in adolescence. The mean serum $25(\mathrm{OH})$ vitamin D level of the children who participated in the study was found as $15.4 \pm 6.5$. Severe vitamin D deficiency was detected in $10(9.7 \%)$ of the children, who were grouped according to their serum 25 $(\mathrm{OH})$ vitamin D levels, vitamin D deficiency in 25 children (24.3\%) and vitamin D insufficiency in 42 children (40.8\%). In total, the serum $25(\mathrm{OH})$ vitamin D levels of 77 children $(74.2 \%)$ were below the normal limit (Figure 1).

When the serum $25(\mathrm{OH})$ vitamin D levels of children and their genders were compared, the serum $25(\mathrm{OH})$ vitamin $\mathrm{D}$ levels in males were discovered to be significantly higher than those in females $(\mathrm{p}=0.04)$. When the age groups and serum $25(\mathrm{OH})$ vitamin D levels were compared, no significant difference was observed ( $\mathrm{p}=0.06)$ (Table 1$)$.

The serum $25(\mathrm{OH})$ vitamin D levels of 40 (83.3\%) female children in our study were found below the normal limits. Of the female children, $5(10.4 \%)$ were found to have a serum

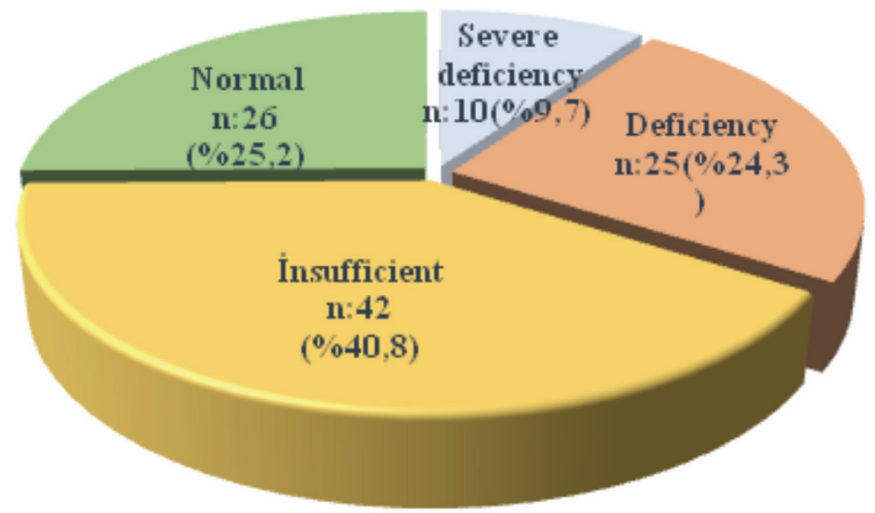

Figure 1. Classification of serum $25(\mathrm{OH})$ vitamin D levels of the cases
$25(\mathrm{OH})$ vitamin D level at the grade of severe deficiency, $16(33.3 \%)$ at the grade of deficiency, and $19(39.6 \%)$ at the grade of insufficient. Serum $25(\mathrm{OH})$ vitamin D levels of 8 (16.7\%) female children were within the normal limits. Serum $25(\mathrm{OH})$ vitamin D levels of 37 (67.3\%) of the male children were below the normal limits. Regarding serum $25(\mathrm{OH})$ vitamin D levels, it was observed that $5(9 \%)$ had severe deficiency, 9 (16.4\%) had deficiency, and 23 (41.8\%) had insufficient levels. Eighteen $(32.7 \%)$ of the male children had normal limits (Figure 2).

In the classification of serum $25(\mathrm{OH})$ vitamin D according to the age groups of the children in our study, the serum $25(\mathrm{OH})$ vitamin D levels of $22(61.1 \%)$ children in the play age, $31(81.5 \%)$ children in the school age and $24(82.7 \%)$ children in adolescence were found to be below the normal limits (Figure 3).

\section{Discussion}

In children, musculoskeletal complaints are quite common. The incidence ranges between $4 \%$ and $30 \%$ $(9,10)$. Non-inflammatory muscle joint pain is among the

Table 1. Comparison of vitamin D levels by age and gender

\begin{tabular}{lllll}
\multicolumn{5}{c}{ Serum 25 (OH) D level } \\
\hline & $\mathbf{n}(\%)$ & Mean \pm SD & $\begin{array}{l}\text { Median } \\
(\mathbf{2 5 p}-75 \mathbf{p})\end{array}$ & $\mathbf{p}$ \\
\hline Gender & & & & \\
Girl & $48(46.6)$ & $14.1 \pm 6.5$ & $12.8(9.6-19)$ & $\mathbf{0 . 0 4 *}$ \\
Boy & $55(53.4)$ & $16.5 \pm 6.4$ & $17(11.8-21.2)$ & \\
Age & & & & \\
Play age & $36(35)$ & $17.3 \pm 6.8$ & $18.4(11.5-22.9)$ & - \\
School period & $38(36.9)$ & $15.2 \pm 6.4$ & $14.1(10.3-19.1)$ & $0.06^{* *}$ \\
Adolescence & $29(28.1)$ & $13.3 \pm 5.8$ & $13.3(9.6-17.2)$ & - \\
\hline *: Mann-Whitney U test, **: Kruskal-Wallis test, SD: Standard deviation &
\end{tabular}

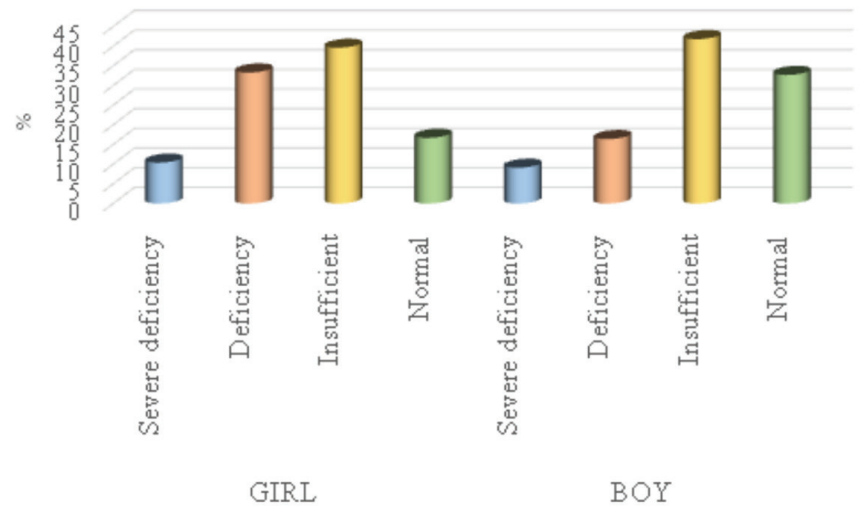

Figure 2. Classification of serum $25(\mathrm{OH})$ vitamin D by gender 


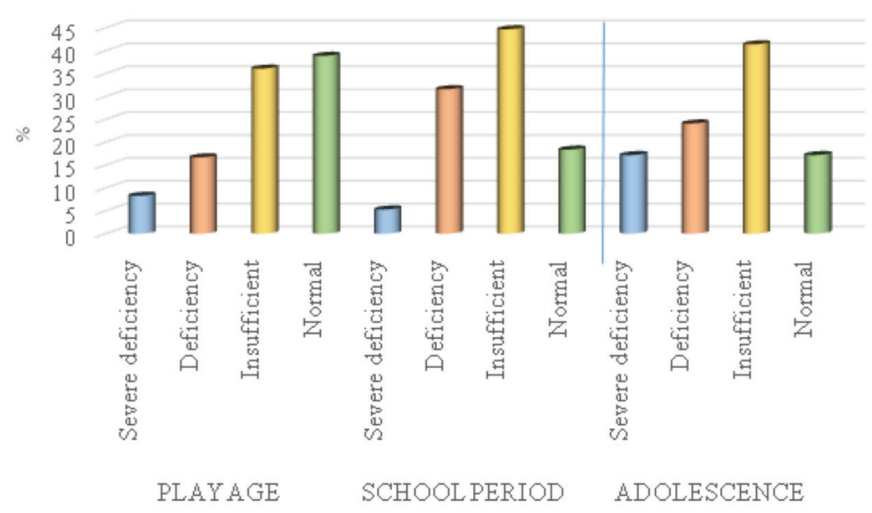

Figure 3. Classification of serum $25(\mathrm{OH})$ vitamin D by age group

most common complaints in childhood. However, other causes must definitely be eliminated (11). If there are other findings such as high fever, malaise, weight loss, decrease in joint movements, edema in the joint, unsymmetrical leg pain or joint stiffness in the morning, the diagnoses of growth pain can be established with the Peterson (3) criteria (atypical growth pains) following the elimination of other causes with more laboratory and X-ray studies.

It is often called growth pains because it affects arms and legs, which is the most obvious evidence of growth. It is generally observed after intense physical activity. Although many researchers try to develop diagnostic criteria, the Peterson (12) criteria based on clinical findings are the most useful. They were completed by Russel and AbuArafeh (13). The criteria for growth pain are based on the current clinical picture of children and the recurrent pain in the lower extremity. There are no trauma, edema, redness, tenderness that can be localized, or other general and regional findings of inflammation. These pains continue for less than 72 hours, cannot be localized in the bone and do not cause movement restriction in more than one joint. The frequency of growth pains is variable $(2.6 \%-49.4 \%)(14)$. In recent studies, the prevalence was found to be $38.3 \%$ in children aged between 4 and 6 years (15). According to the results of our study, there are similar consultations from all age groups.

The biological and physiological mechanisms related to the relationship between vitamin D deficiency and pain and how it causes chronic painful conditions have not been clarified. In in vitro cultures, an inverse relationship has been revealed between vitamin $\mathrm{D}$ levels and the growth of sensory neurons (16). It is believed that sufficient vitamin $\mathrm{D}$ at the cellular level has a protective effect on cell functions and decreases inflammation (9). As a result, it is thought that low vitamin $\mathrm{D}$ increases the pain by increasing inflammation (16). Vitamin D deficiency can disrupt the bone mineralization and cause pain in the joints and muscles related to isolated or prevalent bone pain. In their study conducted on 276 patients, Heidari et al. (17) compared the patients with non-specific musculoskeletal pain and normal healthy individuals, and discovered that vitamin D deficiency especially in female patients was correlated with non-specific musculoskeletal pains.

Even though our country has a geographical location with sunny weather, vitamin D deficiency continues to be a significant problem affecting infants and adolescents $(18,19)$. Worldwide researches conducted to evaluate the vitamin D state of healthy children and the frequency of vitamin D deficiency was found to be between $30 \%$ and $80 \%$ in children and adults $(8,20)$. In a group of Turkish girls aged 14-18 years, the prevalence of vitamin D insufficiency was reported to vary between $15.6 \%$ and $59.4 \%$ according to socio-economic status and season (21). In our study, the rate of vitamin $\mathrm{D}$ deficiency of children who applied with the complaint of musculoskeletal pain is $74.8 \%$, which is the same with those values.

In some researches on healthy children, vitamin $\mathrm{D}$ deficiency was shown to be more frequent in female children (22). In our study, serum $25(\mathrm{OH})$ vitamin D levels of males were found to be significantly higher than those of females.

It is known that vitamin D level is affected by making use of the sunlight, sunscreen usage, nutritional status, vitamin $\mathrm{D}$ content of the diet, daily physical activity amount, socioeconomic level and clothing style (23). One of the most significant limitations of the research is that these factors could not be evaluated since the research was retrospective. In our study, the vitamin D levels by age group were similar, and deficiency was observed in all the groups. Patients with very low vitamin D levels may be eating poorly or making less use of the sunlight.

We wanted to emphasize that other causes should be investigated before the establishment of the diagnosis of the growth pain. Joint complaints are commonly encountered in children, and non-inflammatory causes are the most common causes of the muscle-joint pain. However, growth pain should be diagnosed after eliminating all the organic causes such as rheumatism, infection and malignancy.

In our study, we aimed to emphasize the importance of vitamin D level assessment in patients who consulted for joint-muscle pain and were thought to have growth pain. 


\section{Ethics}

Ethics Committee Approval: The study was approved by the ethics committee of Bakırköy Sadi Konuk Training and Research Hospital with decision no: 2020-254/08.06.202.

Informed Consent: Retrospective study.

Peer-review: Externally peer-reviewed.

\section{Authorship Contributions}

Concept: S.N., E.N., Ö.A.S., Design: S.N., E.N., Ö.A.S., Data Collection or Processing: S.N., Analysis or Interpretation: S.N., F.D., Writing: S.N.

Conflict of Interest: No conflict of interest was declared by the authors.

Financial Disclosure: The authors declared that this study has received no financial support.

\section{References}

1. Al Khattat A, Campell J. Recurrent limb pain in childhood ("growing pains"). Foot 2000;10(3):117-123.

2. Kasapçopur Ö. Çocukluk çağı romatizmal hastalıklarına tanılandırıcı yaklaşım. İ.Ü. Cerrahpaşa Tıp Fakültesi Sürekli Tıp Etkinlikleri, Sempozyum dizisi 2003;34(4):43-50.

3. Peterson H. Growing pains. Pediatr Clin North Am 1986;33(6):13651372.

4. Plotnikoff GA, Quigley JM. Prevalence of severe hypovitaminosis $\mathrm{D}$ in patients with persistent, nonspesific musculoskeletal pain. Mayo Clin Pro 2003;78(12):1463-1470.

5. Pfeifer M, Begerow B, Minne HW. Vitamin D and muscle function. Osteoporos Int 2002;13:187-194.

6. Misra M, Pacaud D, Petryk A, Collett-Solberg PF, Kappy M, Drug and Therapeutics Committee of the Lawson Wilkins Pediatric Endocrine Society. Vitamin D deficiency in children and its management: review of current knowledge and recommendations. Pediatrics 2008;12(2)2:398-417.

7. Grant WB, Holick MF. Benefits and requirements of vitamin D for optimal health: a review. Altern Med Rev 2005;10(2):94-111.
8. Holick MF. Vitamin D deficiency. N Engl J Med 2007;357(3):266281.

9. Goodman JE, McGrath PJ. The epidemiology of pain in children and adolescents: a review. Pain 1991:46(3):247-264.

10. Symmons DP, Jones M, Osborne J, Sills J, Southwood TR, Woo P. Pediatric rheumatology in the United Kingdom: data from the British Pediatric Rheumatology Group National Diagnostic Register. J Rheum 1996;23(11):1975-1980.

11. Cassidy JT, Petty RE. Musculoskeletal Pain Syndromes Of Nonrheumatic Origin. In: Pediatric Rheumatology. 3rd ed., Pennsylvania:Saunders Company, 1995:108-132.

12. Petersen HA. Leg aches. Pediatr Clin North Am 1977;24(4):731-736.

13. Abu-Arafeh I, Russell G. Recurrent limb pain in schoolchildren. Arch Dis Child 1996;74(4):336-339.

14. Williams MF. Rheumatic conditions in school children. Lancet 1928;211(2):720-721.

15. Evans AM, Scutter SD. Prevalence of "Growing Pains" in young children. J Pediatr 2004;145(2):255-258.

16. Glover TL, Goodin BR, Horgas AL, Kindler LL, King CD, Sibille KT, et al. Vitamin D, race, and experimental pain sensitivity in older adults with knee osteoarthritis. Arthritis Rheum 2012;64(12):39263235 .

17. Heidari B, Shirvani JS, Firouzjahi A, Heidari P, Hajian-Tilaki KO Association between nonspecific skeletal pain and vitamin D deficiency. Int J Rheum Dis 2010;13(4):340-346.

18. Özkan B, Döneray H. D vitamininin iskelet sistemi dışı etkileri. Çocuk Sağlığı ve Hastalıkları Dergisi 2011;54(2):99-119.

19. Hatun Ş, Bereket A, Çalıkoğlu AS, Özkan B. Günümüzde D vitamini yetersizliği ve nütrisyonel rikets. Çocuk Sağlığı ve Hastalıkları Dergisi 2003;46:224-241.

20. Salvo MS, Whiting SJ, Barton CN. Vitamin D intake: a global perspective of current status. J Nutr 2005;135(2):310-316.

21. Olmez D, Bober E, Buyukgebiz A, Cimrin D. The frequency of vitamin $\mathrm{D}$ insufficiency in healthy female adolescents. Acta Paediatr 2006;95(10):1266-1269.

22. Pelajo CF, Lopez-Benitez JM, Miller LC. Vitamin D and autoimmune rheumatologic disorders. Autoimmun Rev 2010;9(7):507-510.

23. El-Hajj Fuleihan G, Nabulsi M, Choucair M, Salamoun M, Shahine $\mathrm{CH}$, Kizirian A, et al. Hypovitaminosis D in healthy schoolchildren. Pediatrics 2001;107(4):E53. 